\title{
Dipsas vermiculata Peters, 1960 (Squamata, Colubridae): first country record from Colombia, with description of its hemipenial morphology and comments on its distribution and diagnosis
}

\author{
Luis Enrique Vera-Pérez \\ Independent researcher, carrera 8 \# 2A-12, Las Quintas, La Plata, Huila, Colombia; Luis Enrique Vera-Pérez, dipsadini@gmail.com
}

\begin{abstract}
The Vermiculate Snail-eater Dipsas vermiculata Peters, 1960 is currently known only from the Amazon region of Ecuador and northern Peru. The present study provides the first record of this species from Colombia, extending its distribution northwards by, approximately, $251 \mathrm{~km}$ in a straight line from El Reventador, province of Napo, Ecuador. A detailed description of its fully everted hemipenis is also presented for the first time along with comments on its geographical distribution and identification.
\end{abstract}

Keywords

Alto Fragua Indi-Wasi, Caquetá, Dipsadinae, Ecuador, Peru.

Academic editor: Sebastian Lotzkat | Received 9 November 2019 | Accepted 6 April 2020 | Published 8 May 2020

Citation: Vera-Pérez LE (2020) Dipsas vermiculata Peters, 1960 (Squamata, Colubridae): first country record from Colombia, with description of its hemipenial morphology and comments on its distribution and diagnosis. Check List 16 (3): 527-533. https://doi.org/10.15560/16.3.527

\section{Introduction}

The snail-eating snakes of the genus Dipsas Laurenti, 1768 are distributed in Latin America from Mexico to all South American countries, except Chile (Peters 1960; Peters and Orejas-Miranda 1970; Savage 2002; Wallach et al. 2014). In the latest systematic hypothesis of South American Dipsadini (Arteaga et al. 2018), mainly based on molecular analyses, the genus Sibynomorphus Fitzinger, 1843 was considered a synonym of Dipsas. This, in addition to other taxonomic actions and new species described from Ecuador and Peru, led to 52 species currently comprised within the genus (Arteaga et al. 2018; Uetz et al. 2019).

Dipsas vermiculata Peters, 1960 is distributed on foothills and lowlands of the Amazon of Ecuador and northern Peru in an altitudinal range of 210-1690 m (Peters 1960; Cisneros-Heredia et al. 2016; Orrell 2019;
Pazmiño-Otamendi and Rodríguez-Guerra 2019). This species was initially assigned to the $D$. catesbyi species group mainly based on coloration pattern features (Peters 1960), but Harvey (2008) included it into the $D$. temporalis species group based on additional visceral morphology and scutellation features. Finally, Arteaga et al. (2018) transferred D. vermiculata into the D. variegata species group based exclusively on the results of their molecular analyses.

In March 2012, a group of students from Universidad del Cauca sampling fauna at Parque Nacional Natural Alto Fragua-Indi Wasi, department of Caquetá, Colombia, collected a single specimen of Dipsas that was stored in the herpetological collection of the Museo de Historia Natural of the Universidad del Cauca (MHNUC). A detailed examination of that specimen revealed that it 
represents an individual of $D$. vermiculata, corresponding to the first record in Colombia. The goal of this paper is to report this range extension and to provide additional information on the distribution, morphology, and diagnosis of $D$. vermiculata.

\section{Methods}

Species identification is based on the original description by Peters (1960) as well as additional characteristics provided by Harvey and Embert (2008), Arteaga et al. (2018), and distinguishable details of several specimens photographed in life from the Museo de Zoología of the Pontificia Universidad Católica del Ecuador (QCAZ), compiled by Pazmiño-Otamendi and Rodríguez-Guerra (2019). Locality records were also taken from the aforementioned sources in addition to The Global Biodiversity Information Facility (GBIF Secretariat 2019), especially from datasets provided by Harvard University and Senckenberg (Harvard University and Morris 2019; Senckenberg 2019). Since the voucher from MHNUC has no associated coordinates to locality information, I used those provided for "La Quisayá, 800-1600 m" by Gómez-Bernal et al. (2016). All locality records were verified or assigned using Google Earth Pro version 7.3.2.5776. For vouchers lacking coordinates, those were assigned only if there was a specific given locality to the specimen. All coordinates are in WGS84 datum, all elevations in meters above sea level.

Ventral scale count follows Dowling (1951) and subcaudal scales were counted in pairs, excluding the terminal spine. Total and tail lengths were measured with a ruler to the nearest $1.0 \mathrm{~mm}$ whilst hemipenial measurements were taken with a dial caliper to the nearest 0.1 $\mathrm{mm}$ under a stereoscope. Maxillary teeth were counted on both sides through a narrow incision between the supralabials and the maxillary arch also using the stereoscope. The hemipenis was prepared following the methods of Myers and Cadle (2003) and Zaher and Prudente (2003). Hemipenial terminology follows Dowling and Savage (1960) as supplemented by Myers and Campbell (1981), as well as some of the characters and terms introduced for dipsadines by Harvey and Embert (2008). The organ was photographed with backlight on a glass sheet that was placed on a mirror box, which contained a LED light at its base; a useful technique with which several structures are better appreciable, especially in small organs.

\section{Results}

\section{Dipsas vermiculata Peters, 1960}

New record. COLOMBIA • 1 adult male; Caquetá, Belén de los Andaquíes, La Quisaya, Parque Nacional Natural Alto Fragua Indi-Wasi; 01.5772, -075.9472; alt. 1100 m; 13 Mar. 2012; collected by Jorge Alberto Zúñiga Baos; MHNUC-HE-Se-0697.
Identification. The specimen MHNUC-HE-Se-0697 (Fig. 1) is identified as Dipsas vermiculata according to the following characteristics: an adult male (by presence of hemipenes), slender and laterally compressed body of $591 \mathrm{~mm}$ total length, $417 \mathrm{~mm}$ snout-vent length, $174 \mathrm{~mm}$ tail length (29.4\% of total length); prefrontals fused into a single scale, loreal enters orbit, loreal rectangular and less than twice as long as high, preocular one, postoculars three, temporals $2+2$; supralabials seven, 4 th to 6 th contacting eye orbit; infralabials eight, fist pair in contact behind mental, 1st to 5th (right side) and 1st to 6th (left side) in contact with anterior chinshields; chinshields in four pairs, prevental one, ventrals 187, anal plate entire, paired subcaudals 108; smooth dorsal scales in 13-1313 rows; maxillary teeth 19 , in both sides with a short diastema. Coloration pattern composed by 24 brown to dark brown body blotches, darker on borders, plus $13 / 15$ on tail (right/left side) that are complete anteriorly (bands), alternated posteriorly, separated by light brown interspaces that develop projections at midline of dorsum which connect completely around the midbody to the end of tail, forming a cream line on the vertebral row. Dark blotches are slightly rounded on anterior portion of body but become trapezoidal-shaped (lateral view) on posterior portion of body, where interspaces also become trapezoidal and even triangular. Dorsum of head is dark brown with a cream nuchal band and a strong vermiculation. Most portions of supralabials, infralabials, and ventral surface of head are white with some dark brown spots. Ventral coloration is composed by projections of dorsal blotches, but interspaces are white and extend to first or second dorsal scale rows. Each dark ventral blotch is interrupted by a longitudinal medial clear stripe and white blotches have dark pigment also forming a midventral stripe on first ones. After seven years in preservative, the coloration of the specimen has only slightly faded with respect to that of the live specimen (Fig. 2).

Based on the everted left organ of MHNUC-HESe-0697 (Fig. 3), the hemipenis of D. vermiculata is a cylindrical and slightly elongate organ of $12.8 \mathrm{~mm}$ total length, fully capitated except on the portion near the sulcus spermaticus. Capitulum weakly bilobed and not very bulbous, occupying less than a quarter of the organ's length at level of the pronounced capitular arch (asulcate surface) and around $60 \%$ at the level of sulcus spermaticus (sulcate surface), being ornamented exclusively with spinules that are enlarged on anterior margin and form poorly developed calyces, best appreciated at the distal portion on the sulcate surface. The sulcus spermaticus is deep and forks directly in the capitulum near its proximal edge with branches that extend centrolinearly almost to the tips of the lobes. Hemipenis body is covered by two rows of straight spines (from under the free capitular flap) followed by three rows of curves spines, a short asulcate patch and two subequal basal hooks with a medium-sized spine in the middle (asulcate surface). On the sulcate surface the rows are reduced to three sulcate 


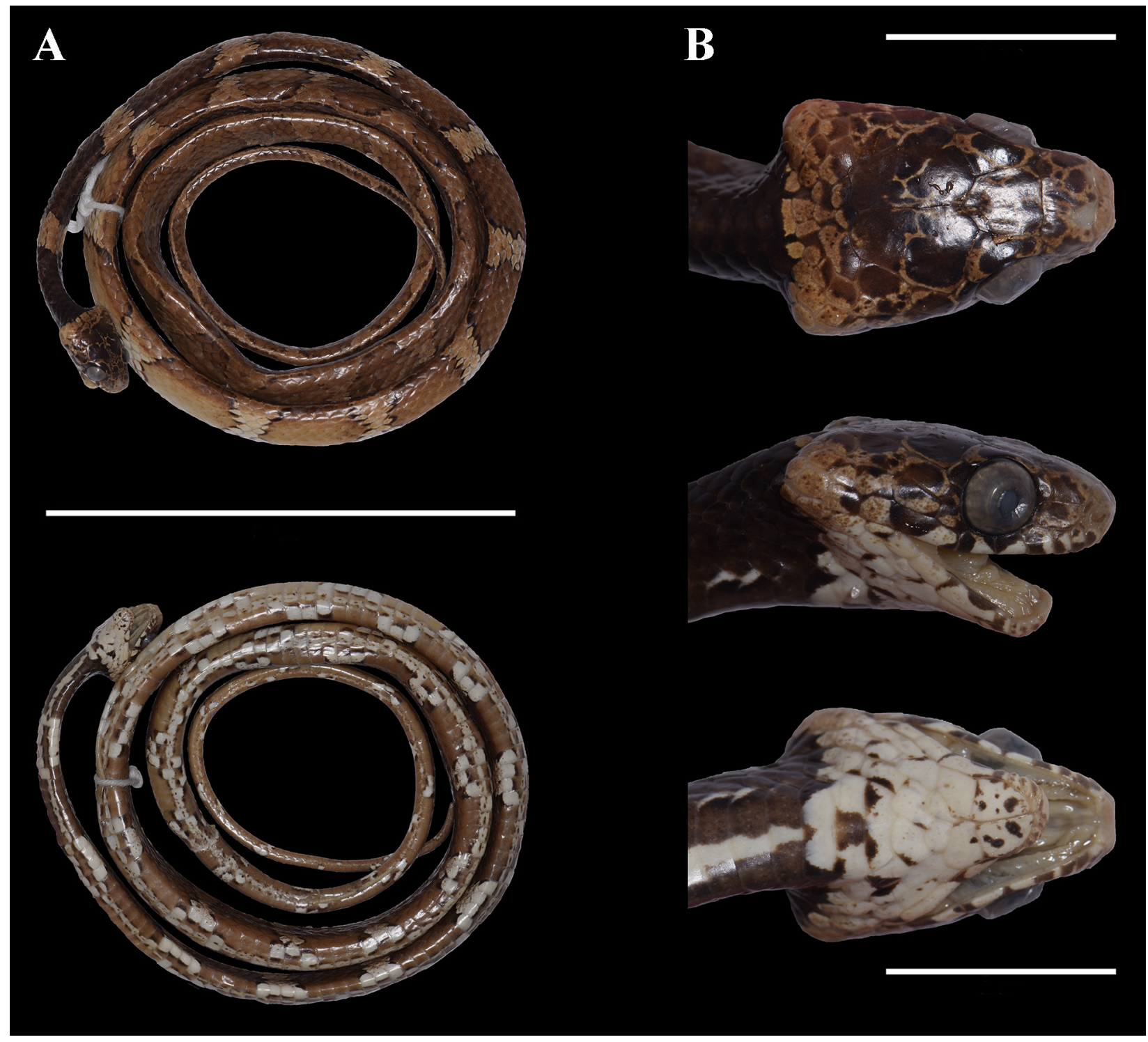

Figure 1. Dipsas vermiculata from Colombia (MHNUC-HE-Se-0697) after seven years preserved in 70\% ethanol. A. General dorsal (upper) and ventral (lower) views. B. Head in dorsal (upper), lateral (middle) and ventral (lower) views. Scale bars: A = $80 \mathrm{~mm} ; \mathrm{B}=10 \mathrm{~mm}$.

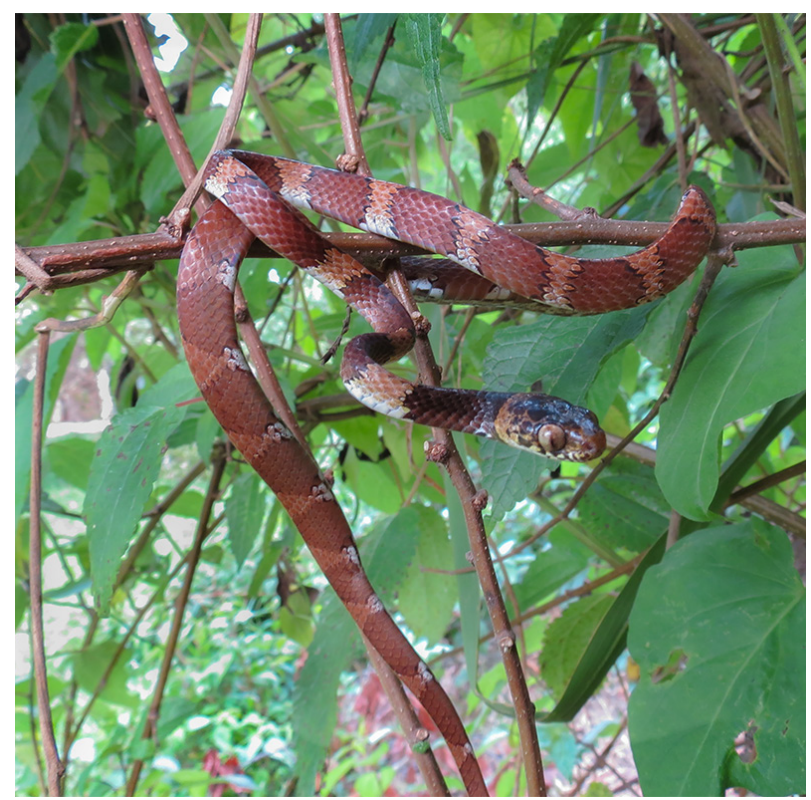

Figure 2. Dipsas vermiculata from Colombia (MHNUC-HE-Se-0697) in life. spine rows (curved). Lateral offset parasulcal spines are barely longer than basal hooks. Many spinules are present among curved spines, near sulcus spermaticus and the base of organ. An elongate (around 35\% of organ length) and deep nude pocket flanked by a pair of fleshy lobes is present on the lateral side between the base of organ and lateral enlarged spines.

\section{Discussion}

The new record presented herein is the first documented occurrence of Dipsas vermicualta in Colombia and corresponds to the northernmost locality of this species, extending its known distribution in about $251 \mathrm{~km}$ in a straight line from El Reventador, province of Napo, Ecuador, to Parque Nacional Natural Alto Fragua IndiWasi, vereda La Quisaya, municipality of Belén de los Andaquíes, department of Caquetá, Colombia (Fig. 4). Records from Ecuadorian paratypes AMNH 35960 and UMMZ 89029 listed by Peters (1960) were not mapped 


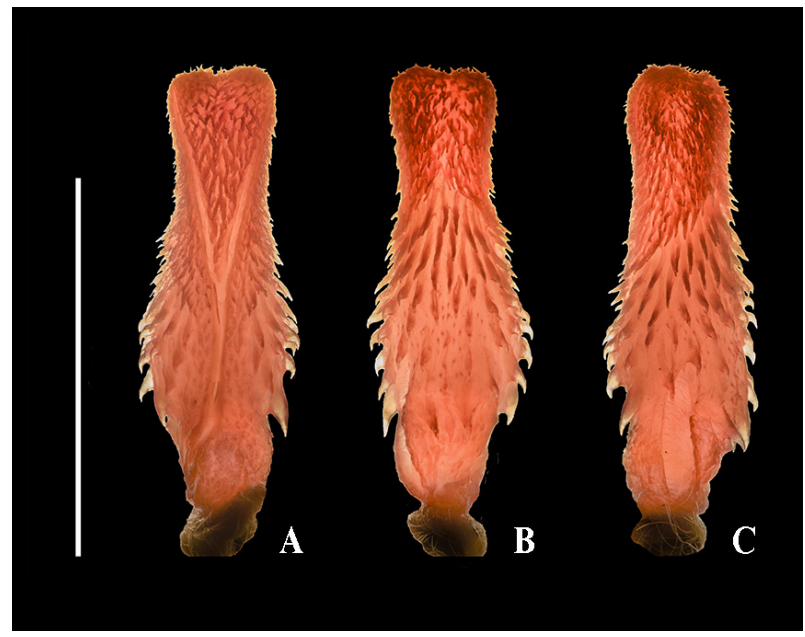

Figure 3. Hemipenis of Dipsas vermiculata (left organ of MHNUCHE-Se-0697). A. Sulcate view. B. Asulcate view. C. Lateral view. Scale bar $=10 \mathrm{~mm}$. due to "Turula" never having been precisely located by any author (see details in Peters 1957 and Savage 1960), and "Rio Napo watershed" could be any place along the Napo river basin, one of the largest in Ecuador that comprises an altitudinal gradient of more than $5000 \mathrm{~m}$ (Lessmann et al. 2016) and an area of $27000 \mathrm{~km}^{2}$, equivalent to $20 \%$ of the eastern part of this country (Laraque et al. 2009). The Peruvian paratype AMNH 55889, likewise, lacks coordinates but those were inferred from the given locality "Far upper Rio Santiago" (-03.5091, -077.7979); whilst the type locality "Chichirota, Ecuador" can be assumed to be the same as for specimen USNM 196350 (-02.3833, -076.65) (Orrell 2019).

The record of the specimen SBH 171139 from Pasco, Peru, incorrectly listed as "SBI 171139" by Arteaga et al. (2018), was excluded from the locality records of $D$. vermiculata (Appendix Table A1) because (1) the locality

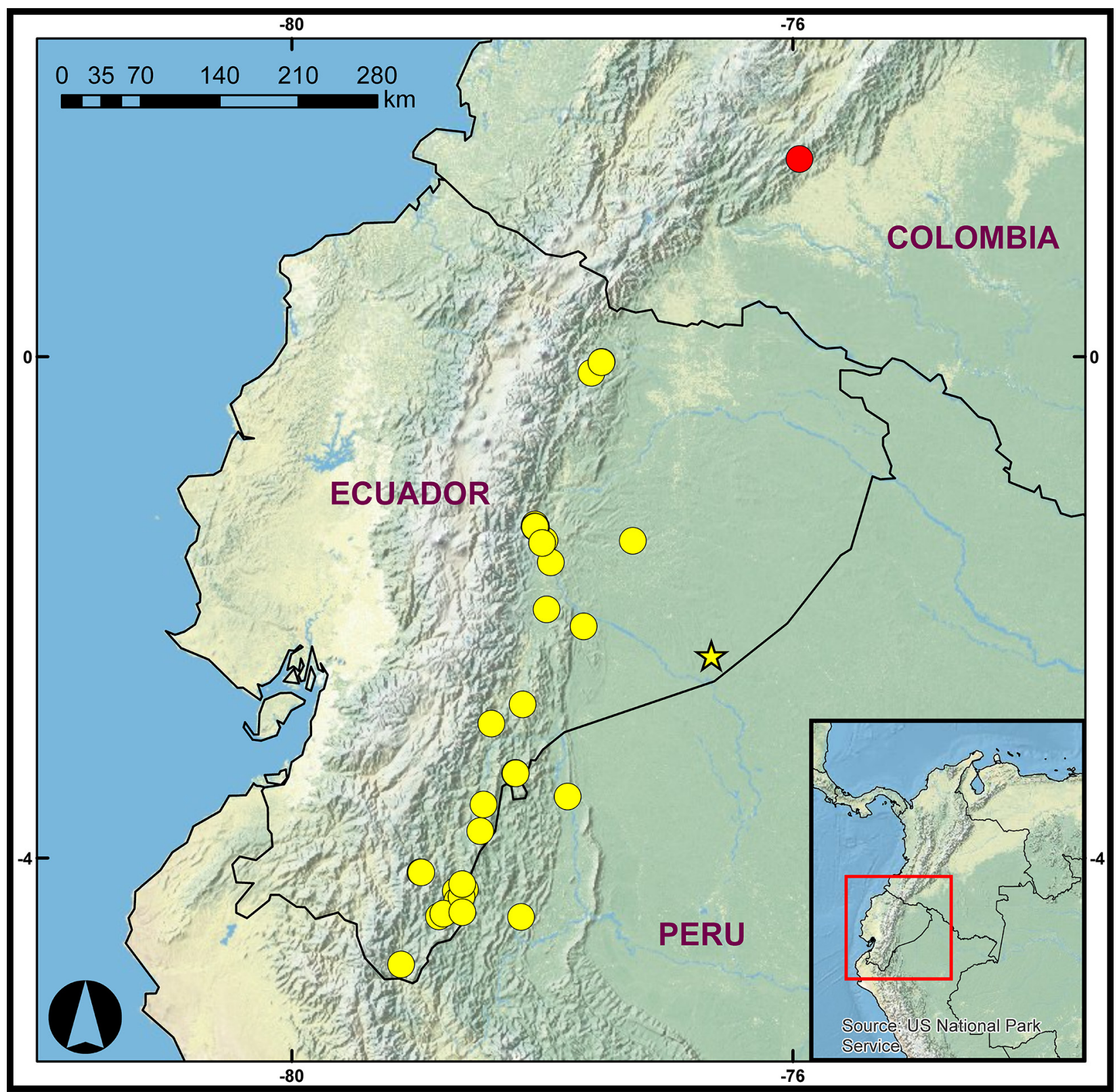

Figure 4. Geographic distribution of Dipsas vermiculata. Yellow dots indicate previously published records from Ecuador and Peru. Red dot indicates the new record from Colombia. Star indicates the type locality. 
suggests an enormous distribution gap of more than 760 $\mathrm{km}$ in a straight line in relation to southernmost records from Ecuador and Peru; (2) the specimen appears initially referenced as $D$. catesbyi (Sentzen, 1796) by Heise et al. (1995); (3) it was not examined and the change of its identity to D. vermiculata is only based on DNA sequence analyses; (4) this change was apparently influenced by an inadequate comparison where sequences of $12 \mathrm{~S}$ gene are lacking for several species of Dipsas including the most closely related and/or similar ones such as D. pakaraima MacCulloch \& Lathrop, 2004, D. pavonina Schlegel, 1837, and D. temporalis (Werner, 1909) (see Arteaga et al. 2018: appendix 1); and (5) the $12 \mathrm{~S}$ and $16 \mathrm{~S}$ gene sequences (GenBank accession numbers Z46459 and Z46496, respectively) associated with specimen SBH 171139 by Arteaga et al. (2018), actually belong to two different specimens (see Material and Methods in Heise et al. 1995).

The specimen MHNUC-HE-Se-0697 has most morphological characteristics diagnoseable for $D$. vermiculata as described in published reviews (Peters 1960; Harvey and Embert 2008; Arteaga et al. 2018), except for 24 dark-bordered dark blotches (vs up to 23 lightbordered) and three postoculars (vs 1-2). However, high-resolution photos in life from Ecuadorian specimens (Pazmiño-Otamendi and Rodríguez-Guerra 2019) reveal that the species can have up to at least 25 dark body blotches (e.g. QCAZ 16201), up to four postoculars (QCAZ 16086, 16201), and "light borders" actually correspond to interspaces. Additionally, some specimens have small subpreocular and temporal scale counts that were not previously reported in literature (3 anterior, 3-4 posterior temporals). A more detailed revision of additional specimens is necessary to improve the description of this species.

Hemipenial morphology of $D$. vermiculata shows high similarity with that described for $D$. variegata (Duméril, Bibron \& Duméril, 1854) (Porto and Fernandes 1996; Cadle and Myers 2003). Organs of both species share a slightly elongate shape, a not very bulbous capitulum with some bilobation, lacking papillae and covered only by spinules, a noticeably capitular arch, and 4-5 asulcate spine rows on the body. This similarity further supports the assignment of both species into the same species group as suggested by molecular analyses, and the removal of $D$. vermiculata from the $D$. temporalis group established by Arteaga et al. (2018), as the hemipenis of $D$. temporalis has few asulcate spine rows on the body and papillate calyces uniformly covering the capitulum (Harvey 2008; Harvey and Embert 2008). Likewise, there are notable differences between hemipenial morphology of D. vermiculata and D. pakaraima (see description in MacCulloch and Lathrop 2004) mainly in terms of the organ shape, capitulum arch, capitulum length, and sulcus spermaticus division, supporting the view that they do not belong to the same species group despite their resemblances in several other characters (Harvey 2008).

\section{Acknowledgements}

I am grateful to Santiago Ayerbe, Jorge Zúñiga Baos, Andrés Felipe Liévano Bonilla and my professors at Universidad del Cauca specially to María del Pilar Rivas, María Cristina Gallego and Jimmy Guerrero from Museo de Historia Natural for the unconditional support they have given to me. Finally, my warmest thanks to Giovanna G. Montingelli and Paola Sanchez for teaching to me the techniques of hemipenial preparation, and to Juan Pablo Ramírez for his helpful suggestions on this manuscript.

\section{References}

Arteaga A, Salazar-Valenzuela D, Mebert K, Peñafiel N, Aguiar G, Sánchez-Nivicela JC, Pyron RA, Colston TJ, Cisneros-Heredia DF, Yánez-Muñoz MH, Venegas PJ, Guayasamin JM, TorresCarvajal O (2018) Systematics of South American snail-eating snakes (Serpentes, Dipsadini), with the description of five new species from Ecuador and Peru. ZooKeys 766: 79-147. https://doi. org/10.3897/zookeys.766.24523

Cadle JE, Myers CW (2003) Systematics of snakes referred to Dipsas variegata in Panama and Western South America, with revalidation of two species and notes on defensive behaviors in the Dipsadini (Colubridae). American Museum Novitates 3409: 1-47. https://doi.org/10.1206/0003-0082(2003)409 $<0001$ : $\operatorname{sos} r t d>2.0 . \operatorname{co} ; 2$

Cisneros-Heredia DF, Yánez-Muñoz M, Almendáriz A, Valencia J, Segovia J, Torres C (2016) Dipsas vermiculata. The IUCN Red List of Threatened Species 2016: e.T50951315A50951320. https:// www.iucnredlist.org/species/50951315/50951320. Accessed on: 2019-10-5.

Dowling HG (1951) A proposed standard system of counting ventrals in snakes. British Journal of Herpetology 1: 97-99.

Dowling HG, Savage JM (1960) A guide to the snake hemipenis: A survey of basic structure and systematic characteristics. Zoologica 45: 17-28.

Duméril AMC, Bibron G, Duméril AHA (1854) Erpétologie générale ou Histoire Naturelle complète des Reptiles. Librairie Encycolpédique de Roret, Paris, 780 pp.

Fitzinger L (1843) Systema reptilium. Fasciculus primus, Amblyglossae. Braumüller et Seidel, Vienna, 106 pp. https://doi.org/10.5962/ bhl.title.4694

GBIF Secretariat (2019) Dipsas vermiculata Peters, 1960. GBIF Backbone Taxonomy. https://doi.org/10.15468/39omei. Accessed on: 2019-5-25.

Gómez-Bernal LG, Ayerbe-Quiñones F, Negret PJ (2016) Nuevos registros de aves en el piedemonte amazónico colombiano. Cotinga 38: $23-31$.

Harvard University M, Morris PJ (2019) Museum of Comparative Zoology, Harvard University. Version 162.175. Museum of Comparative Zoology, Harvard University. https://doi.org/10.15468/ p5rupv. Accessed on: 2019-8-26.

Harvey MB (2008) New and poorly known Dipsas (Serpentes: Colubridae) from Northern South America. Herpetologica 64: 422-451. https://oi.org/10.1655/07-068R1.1

Harvey MB, Embert D (2008) Review of Bolivian Dipsas (Serpentes: Colubridae), with comments on other South American species. Herpetological Monographs 22: 54-105. https://doi.org/10. 1655/07-023.1

Heise PJ, Maxson LR, Dowling HG, Hedges SB (1995) Higher-level snake phylogeny inferred from mitochondrial DNA sequences of $12 \mathrm{~S}$ rRNA and 16S rRNA genes. Molecular Biology and Evolution 12 (2): 259-265.

Laraque A, Bernal C, Bourrel L, Darrozes J, Christophoul F, Armi- 
jos E, Fraizy P, Pombosa R, Guyot (2009) Sediment budget of the Napo River, Amazon basin, Ecuador and Peru. Hydrological Processes 23: 3509-3524. https://doi.org/10.1002/hyp.7463

Laurenti NJ (1768) Specimen medicum, exhibens synopsin reptilium emendatam cum experimentis circa venena et antidota reptilium austriacorum. Joan Thom, Vienna, 214 pp. https://doi org/10.5962/bhl.title. 5108

Lessmann J, Guayasamin JM, Casner KL, Flecker AS, Funk WC, Ghalambor CK, Gill BA, Jácome-Negrete I, Kondratieff BC, Poff LN, Schreckinger J, Thomas SA, Toral-Contreras E, Zamudio KR, Encalada, AC (2016) Freshwater vertebrate and invertebrate diversity patterns in an Andean-Amazon basin: implications for conservation efforts. Neotropical Biodiversity 2 (1): 99-114. https://doi.org/10.1080/23766808.2016.1222189

MacCulloch RD, Lathrop A (2004) A new species of Dipsas (Squamata: Colubridae) from Guyana. Revista de Biología Tropical 52: 239-247. https://doi.org/10.15517/rbt.v52i1.14916

Martínez-Fonseca JG, Loza J, Fernández M, Salazar-Saavedra M, Sunyer J (2019) First country record of Rhinobothryum bovallii (Anderson, 1916) (Squamata, Colubridae) from Nicaragua. Check List 15 (4): 555-563. https://doi.org/10.15560/15.4.555

Myers CW, Campbell JA (1981) A new genus and species of colubrid snake from the Sierra Madre del Sur of Guerrero, Mexico. American Museum Novitates 2708: 1-20.

Myers CW, Cadle JE (2003) On the snake hemipenis, with notes on Psomophis and techniques of eversion: a response to Dowling. Herpetological Review 34: 295-302.

Orrell T (2019) NMNH Extant Specimen Records. Version 1.24. National Museum of Natural History, Smithsonian Institution, Washington, DC. https://doi.org/10.15468/hnhrg3. Accessed on: 2019-8-26.

Pazmiño-Otamendi G, Rodríguez-Guerra A (2019) Dipsas vermiculata. In: Torres-Carvajal O, Pazmiño-Otamendi G, Salazar-Valenzuela D (2019) Reptiles del Ecuador. Version 2019.0. Museo de Zoología, Pontificia Universidad Católica del Ecuador. https:// bioweb.bio/faunaweb/reptiliaweb/FichaEspecie/Dipsas\%20 vermiculata. Accessed on: 2019-8-24.

Peters JA (1957) Taxonomic notes on Ecuadorian snakes in the American Museum of Natural History. American Museum Novitates 1851: 1-13.

Peters JA (1960) The snakes of the subfamily Dipsadinae. Museum of Zoology at the University of Michigan Miscellaneous Publications 114: 1-224.

Peters JA, Orejas-Miranda B (1970) Catalogue of the Neotropical Squamata. Part I. Snakes. Smithsonian Institution Press, Washington, DC, $347 \mathrm{pp}$.

Porto M, Fernandes R (1996) Variation and natural history of the snaileating snake Dipsas neivai (Colubridae: Xenodontinae). Journal of Herpetology 30: 269-271. https://doi.org/10.2307/1565522

Savage JM (1960) A revision of the Ecuadorian snakes of the Colubrid genus Atractus. Miscellaneous Publications of the Museum of Zoology, University of Michigan 112: 1-86.

Savage JM (2002) The amphibians and reptiles of Costa Rica. A herpetofauna between two continents, between two seas. The University of Chicago Press, Chicago, 934 pp.

Schlegel H (1837) Essai sur la physionomie des serpens. Partie Descriptive. M. H. Schonekat, Amsterdam, 606 pp.

Senckenberg (2019) Collection Herpetology SMF. https://doi. org/10.15468/lkc3vq. Accessed on: 2019-8-26.

Sentzen UJ (1796) Ophiologische Fragmente. Meyer's Zoologische Stockholm Archiv 2: 59-66.

Uetz P, Freed P, Hošek J (2019) The Reptile Database. http://www. reptile-database.org. Accessed on: 2020-3-9.

Wallach V, Williams KL, Boundy J (2014) Snakes of the world. A catalogue of living and extinct species. CRC Press, Boca Ratón, 1237 pp. https://doi.org/10.1201/b16901

Werner F (1909) Über neue oder seltene Reptilien des Naturhistorischen Museums in Hamburg. Jahrbuch der Hamburgischen Wissenschaftlichen Anstalten 26: 205-247.

Zaher H, Prudente AL (2003) Hemipenes of Siphlophis (Serpentes, Xenodontinae) and techniques of hemipenial preparation in snakes: A response to Dowling. Herpetological Review 34: 302-307.

\section{Appendix}

Table A1. Locality records of Dipsas vermiculata. Sources of coordinates are provided in references. $\dagger$ type locality; $\neq$ coordinates assigned from a given locality. Modified from Martínez-Fonseca et al. (2019).

\begin{tabular}{|c|c|c|c|c|c|c|}
\hline \multirow{2}{*}{ Country } & \multirow{2}{*}{ Locality } & \multicolumn{2}{|c|}{ Geographic coordinates } & \multirow{2}{*}{$\begin{array}{l}\text { Alt. } \\
(\mathrm{m})\end{array}$} & \multirow{2}{*}{ Reference } & \multirow{2}{*}{ Voucher } \\
\hline & & Latitude & Longitude & & & \\
\hline Colombia & $\begin{array}{l}\text { Caquetá: Belén de los Andaquíes, La Quisaya, PNN Alto Fragua } \\
\text { Indi-Wasi }\end{array}$ & 01.5772 & -75.9472 & 1100 & This work & $\begin{array}{l}\text { MHNUC-HE- } \\
\text { Se-0697 }\end{array}$ \\
\hline \multirow[t]{15}{*}{ Ecuador } & Turula & - & - & - & Peters (1960) & AMNH 35960 \\
\hline & Napo river watershed & - & - & - & Peters (1960) & UMMZ 89029 \\
\hline & $\begin{array}{l}\text { Morona Santiago: Marantian Wildlife Refuge, Macuma river, } 3 \mathrm{~km} \mathrm{E} \\
\text { of Macuma }\end{array}$ & -02.152 & -077.6706 & 590 & Pazmiño-Otamendi and Rodríguez-Guerra (2019) & QCAZ 17367 \\
\hline & Morona Santiago: Lower part of Cordillera de Cutucú & -02.7742 & -078.1577 & 1360 & Pazmiño-Otamendi and Rodríguez-Guerra (2019) & QCAZ 16201 \\
\hline & $\begin{array}{l}\text { Morona Santiago: Comunidad Shuar Kunkuk, base of Cordillera del } \\
\text { Cóndor }\end{array}$ & -03.3243 & -078.2129 & 1150 & Pazmiño-Otamendi and Rodríguez-Guerra (2019) & QCAZ 16084 \\
\hline & $\begin{array}{l}\text { Morona Santiago: Comunidad Shuar Kunkuk, base of Cordillera del } \\
\text { Cóndor }\end{array}$ & -03.3203 & -078.2146 & 1060 & Pazmiño-Otamendi and Rodríguez-Guerra (2019) & QCAZ 16086 \\
\hline & $\begin{array}{l}\text { Morona Santiago: Comunidad Shuar Kunkuk, base of Cordillera del } \\
\text { Cóndor }\end{array}$ & -03.3243 & -078.2167 & 1060 & Pazmiño-Otamendi and Rodríguez-Guerra (2019) & QCAZ 16087-88 \\
\hline & $\begin{array}{l}\text { Morona Santiago: Limón, Gral. Leonidas Plaza Gutiérrez, } 6.6 \text { km N via } \\
\text { Macas }\end{array}$ & -02.9267 & -078.407 & 1000 & Pazmiño-Otamendi and Rodríguez-Guerra (2019) & QCAZ7452 \\
\hline & Morona Santiago: Buffer zone of El Zarza Wildlife Refuge & -03.7843 & -078.496 & 1470 & Pazmiño-Otamendi and Rodríguez-Guerra (2019) & QCAZR15975 \\
\hline & Morona Santiago: Chiguaza & -02.0167 & -077.9667 & - & $\begin{array}{l}\text { Orrell (2019). https://www.gbif.org/ } \\
\text { occurrence/1320345587 }\end{array}$ & USNM 210973 \\
\hline & Morona Santiago: ECSA concession & -03.5724 & -078.4698 & 790 & Arteaga et al. (2018) & DHMECN 11197 \\
\hline & Napo: Río Salado, 14.7 km (by road) NE of & -00.1289 & -077.6083 & 1310 & $\begin{array}{l}\text { Orrell (2019). https://www.gbif.org/ } \\
\text { occurrence/1319979381 }\end{array}$ & USNM 286337 \\
\hline & Pastaza: Llanganates National Park, Zarentza Community & -01.3543 & -078.0621 & 1390 & Pazmiño-0tamendi and Rodríguez-Guerra (2019) & QCAZ 13563 \\
\hline & Pastaza: Llanganates National Park, Zarentza Community & -01.3626 & -078.0582 & 1350 & Pazmiño-Otamendi and Rodríguez-Guerra (2019) & QCAZ 13564, 65 \\
\hline & Pastaza: Llanganates National Park, Zarentza Community & -01.3587 & -078.0511 & 1340 & Pazmiño-Otamendi and Rodríguez-Guerra (2019) & QCAZ 13566 \\
\hline
\end{tabular}




\begin{tabular}{|c|c|c|c|c|c|c|}
\hline \multirow{2}{*}{ Country } & \multirow{2}{*}{ Locality } & \multicolumn{2}{|c|}{ Geographic coordinates } & \multirow{2}{*}{$\begin{array}{l}\text { Alt. } \\
(\mathrm{m})\end{array}$} & \multirow{2}{*}{ Reference } & \multirow{2}{*}{ Voucher } \\
\hline & & Latitude & Longitude & & & \\
\hline \multirow[t]{22}{*}{ Ecuador } & Pastaza: Llanganates National Park, Zarentza Community & -01.3397 & -078.0595 & 1360 & Pazmiño-Otamendi and Rodríguez-Guerra (2019) & QCAZ 13567 \\
\hline & Pastaza: Llanganates National Park, Zarentza Community & -01.3593 & -078.0574 & 1330 & Pazmiño-Otamendi and Rodríguez-Guerra (2019) & QCAZ 13582 \\
\hline & Pastaza: Santana Field Station & -01.6412 & -077.9327 & - & $\begin{array}{l}\text { Senckenberg (2019). https://www.gbif.org/ } \\
\text { occurrence/318397025 }\end{array}$ & $\begin{array}{l}\text { SMF 90988, } \\
93054\end{array}$ \\
\hline & Pastaza: 1 km W El Puyo & -01.4867 & -078.0022 & - & $\begin{array}{l}\text { Harvard University and Morris (2019). https:// } \\
\text { www.gbif.org/occurrence/476774914 }\end{array}$ & MCZ R-147184 \\
\hline & †Pastaza: Chichirata (Chichirota) & -02.3833 & -076.65 & - & Peters (1960), Orrell (2019) & $\begin{array}{l}\text { EPN 740, 41; } \\
\text { USNM } 196350\end{array}$ \\
\hline & Pastaza: Puyo, below, Shilcayacu river & -01.4667 & -077.9833 & - & $\begin{array}{l}\text { Orrell (2019). https://www.gbif.org/ } \\
\text { occurrence/1322531597 }\end{array}$ & USNM 210972 \\
\hline & Pastaza: Kallana & -01.4696 & -077.2784 & 320 & Arteaga et al. (2018) & MZUTI 5080 \\
\hline & Pastaza: Tzarentza & -01.3570 & -078.0581 & 1360 & Arteaga et al. (2018) & MZUTI 4738 \\
\hline & Sucumbíos: El Reventador & -00.0448 & -077.5286 & 1480 & $\begin{array}{l}\text { Arteaga et al. (2018), Pazmiño-0tamendi and } \\
\text { Rodríguez-Guerra (2019) }\end{array}$ & MHNG 2436.014 \\
\hline & Sucumbíos: El Reventador & -00.0412 & -077.5268 & - & Pazmiño-Otamendi and Rodríguez-Guerra (2019) & QCAZ666 \\
\hline & $\begin{array}{l}\text { Zamora Chinchipe: Las Orquídeas, Tepuy, } 4 \text { km from Nangaritza river } \\
\text { (barge) towards Tepuy }\end{array}$ & -04.2632 & -078.6911 & 1840 & Pazmiño-Otamendi and Rodríguez-Guerra (2019) & QCAZ 9173 \\
\hline & Zamora Chinchipe: Nangaritza river, Shaime & -04.341 & -078.68 & 1000 & Pazmiño-Otamendi and Rodríguez-Guerra (2019) & QCAZ3723 \\
\hline & Zamora Chinchipe: Cordillera del Cóndor & -04.2503 & -078.6174 & - & Pazmiño-Otamendi and Rodríguez-Guerra (2019) & QCAZ7401 \\
\hline & Zamora Chichipe: Parque Nacional Podocarpus, Bombuscaro & -04.1146 & -078.967 & 980 & Pazmiño-Otamendi and Rodríguez-Guerra (2019) & QCAZ 13825 \\
\hline & Zamora Chichipe: Parque Nacional Podocarpus, Bombuscaro & -04.1120 & -078.9726 & 1540 & Pazmiño-Otamendi and Rodríguez-Guerra (2019) & QCAZ 13826 \\
\hline & Zamora Chichipe: Reserva Natural Maycu & -04.2072 & -078.6399 & 870 & $\begin{array}{l}\text { Arteaga et al. (2018); Pazmiño-0tamendi and } \\
\text { Rodríguez-Guerra (2019) }\end{array}$ & MZUTI 3663 \\
\hline & Zamora Chichipe: Reserva Natural Maycu & -04.2089 & -078.6398 & 880 & Pazmiño-Otamendi and Rodríguez-Guerra (2019) & QCAZ 15422 \\
\hline & Zamora Chichipe: Via Miazi-Nuevo Paraiso & -04.3092 & -078.645 & 1010 & Pazmiño-Otamendi and Rodríguez-Guerra (2019) & QCAZ 15423 \\
\hline & Zamora Chinchipe: Surroundings of Ciudad Perdida & -04.4432 & -078.7906 & 1120 & Pazmiño-Otamendi and Rodríguez-Guerra (2019) & QCAZ 15735 \\
\hline & Zamora Chinchipe: Surroundings of Ciudad Perdida & -04.4652 & -078.8257 & 1224 & Pazmiño-Otamendi and Rodríguez-Guerra (2019) & QCAZ 15736 \\
\hline & Zamora Chinchipe: Nangaritza & -04.4317 & -078.6387 & 1010 & Arteaga et al. (2018) & MZUA.RE.0261 \\
\hline & Zamora Chinchipe: 69 km S Vilcabamba & -04.8492 & -079.1273 & 1310 & Arteaga et al. (2018) & MHNG 2521.085 \\
\hline \multirow[t]{2}{*}{ Peru } & ¥Amazonas: Gananashe, Far upper Río Santiago & -03.5091 & -077.7979 & - & Peters (1960) & AMNH 55889 \\
\hline & Amazonas: Huampami, near Etseketai entse, on the Cenepa river & -04.47 & -078.17 & 210 & Orrell (2019) & $\begin{array}{l}\text { USNM 316599, } \\
600\end{array}$ \\
\hline
\end{tabular}

